\title{
PENGEMBANGAN MEDIA PEMBELAJARAN BERBASIS VIRTUAL REALITY (VR) PADA MATERI SISTEM PEREDARAN DARAH
}

\author{
1Badrus Sifa', ${ }^{2}$ Haning Hasbiyati, ${ }^{3}$ Benny Afandi \\ ${ }_{123}$ Pendidikan Biologi, Universitas Islam Jember \\ 1badrussifak@gmail.com,2haninghasbiyati@gmail.com,3b2nafandi@gmail.com
}

\begin{abstract}
ABSTRAK
Pengembangan Media Pembelajaran Berbasis Virtual Reality bertujuan untuk mengetahui kelayakan media ini dalam pembelajaran. Pengembangan media ini menggunakan langkah pengembangan Research and Development menurut Borg \& Gall. Media ini divalidasi kepada ahli media dan ahli materi. Validasi oleh ahli media mendapat nilai dengan persentase $90,91 \%$ dan validasi oleh ahli materi mendapatkan nilai dengan persentase $95,24 \%$, yang berarti sangat valid. Uji coba produk dengan sampel sebanyak 14 orang, mendapat skor dengan persentase $86,20 \%$ (sangat valid), sedangkan uji coba pemakaian dilakukan dengan sampel sebanyak 18 orang mendapatkan skor dengan persentase sebesar $85,10 \%$ (sangat valid). Dari hasil uji coba ini dapat dimaknai bahwa media pembelajaran ini sangat layak dan dapat diimplementasikan ke dalam pembelajaran sebenarnya..
\end{abstract}

Kata kunci: Pengembangan Media pembelajaran, Virtual Reality, Sistem Peredaran Darah.

\section{ABSTRACT}

This Development of Learning Media Based on Virtual Reality aims to find out the feasibility of this media in learning class. The development of this media uses the steps of Research and Development method according to Borg $\mathcal{E}$ Gall. This media is validated to media experts and learning content experts. Validation by media experts gets a value of $90.91 \%$ and validation by learning content experts gets a value of $95.24 \%$, which means it is very valid. Trial products with a sample of 14 peoples, got a score with a percentage of $86.20 \%$ (very valid), while the trial use of a sample of 18 peoples got a score with a percentage of $85.10 \%$ (very valid). From the results of this trial it can be interpreted that this learning media is very feasible and can be implemented into actual learning.

Key words: Learning Media Development, Virtual Reality, bloodstream system

\section{PENDAHULUAN}

Perkembangan teknologi tidak bisa dilepaskan dari perkembangan peradaban manusia. Bahkan perkembangan teknologi dapat diaplikasikan ke dalam pembelajaran. Contohnya adalah Media Pembelajaran. Penggunaan media pembelajaran dalm proses belajar materi biologi sangat dibutuhkan, terutama bahasan yang sifatnya abstrak, tidak dapat divisualisasikan dengan mudah. Semisal, sistem peredaran darah.
Maka, dengan media pembelajaran berbasis virtual reality memungkinkan untuk memvisualkan bagian abstrak tersebut dalam bentuk tiga dimensi. Sehingga materi yang disampaikan bisa lebih menarik dan lebih dipahami.

\section{Rumusan Masalah}

Apakah media pembelajaran berbasis virtual reality layak digunakan sebagai media pembelajaran pada materi sistem peredaran darah pada manusia pada mahasiswa Pendidikan Biologi FKIP Universitas Islam Jember? 
Tujuan Penelitian

Tujuan penelitian ini adalah untuk mengetahui kelayakan media pembelajaran berbasis virtual reality sebagai media pembelajaran pada materi sistem peredaran darah manusia pada mahasiswa Pendidikan Biologi Fakultas Keguruan dan Ilmu Pendidikan Universitas Islam Jember.

\section{METODE PENELITIAN}

\section{Langkah-langkah Penelitian}

Pengembangan media pembelajaran ini menggunakan metode Reasearch and Development menurut Borg and Gall yang dikutip dari Sugiyono (2011).

Langkah-langkah penelitian tersebut adalah: 1) Riset dan Pengumpulan Informasi, 2) Perencanaan, 3) Desain Produk, 4) Validasi Desain, 5) Revisi Desain, 6) Uji Coba Produk, 7) Revisi Produk, 8) Uji Coba Pemakaian, 9) Revisi produk, 10) Desiminasi atau Implementasi.

\section{Subjek/Objek Penelitian}

Tempat, Program Studi Pendidikan Biologi.

\section{Sampel}

Sampel yang digunakan adalah mahasiswa Semester VIII untuk uji coba produk, dan mahasiswa Semester VI untuk uji coba pemakaian.

\section{Metode Pengumpulan Data}

Tahap I

Wawancara, dilakukan pada saat pengumpulan informasi.

Kuisioner, digunakan pada saat validasi oleh ahli dan uji coba produk.
Dokumentasi, pengambilan gambar pada saat wawancara, proses validasi dan uji coba produk

Tahap II

Kuisioner, digunakan pada saat uji coba pemakaian.

Dokumentasi, pengambilan gambar pada saat uji coba pemakaian.

\section{Analisis Data}

Untuk menganalisis data yang didapatkan dari validasi ahli dan uji coba, menggunakan formula:

$$
\text { Persentase }=\frac{x \text { total }}{x \text { max }} \times 100 \%
$$

Selanjutnya, nilai persentase yang didapatkan, di interpretasikan menggunakan kriteria (menurut Arikunto, 2010) sebagaimana berikut:

$$
\begin{array}{ll}
76 \%-100 \% & =\text { Sangat Baik/ layak } \\
56 \%-75 \% & =\text { Baik/ Layak } \\
40 \%-56 \% & =\text { Kurang Baik/ Layak } \\
0 \%-40 \% & =\text { Tidak Baik/Layak }
\end{array}
$$

\section{HASIL DAN PEMBAHASAN}

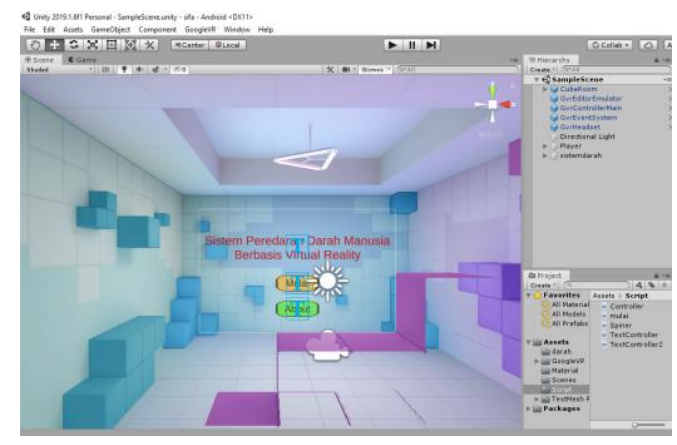

Gambar 1. Tampilan media pembelajaran.

Proses validasi dilakukan dua kali, yaitu kepada ahli media dan ahli materi. Skor validasi ahli media mendapatkan persentase sebesar 90,91\% (sangat valid), dan skor dari validasi oleh ahli materi 
medapatkan persentase sebesar 95,24\% (sangat valid), sehingga dapat dilanjutkan ke tahap berikutnya, setelah perbaikan yang didapatkan pada saat validasi oleh ahli.

Uji coba produk pada mahasiswa Semester VIII, menggunakan sampel sebanyak 14 orang. Dari uji coba tersebut, persentase skor total yang didapatkan sebesar $86,20 \%$, artinya sangat layak untuk digunakan.

Selanjutnya, uji coba pemakaian oleh mahasiswa Semester VI. Sampel yang digunakan sebanyak 18 orang. Persentase skor yang didapatakn sebesar 85,10\%. Dari uji coba pemakaian diketahui bahwa media ini sangat layak dan dapat diimplementasikan ke dalam pembelajaran sebenarnya.

\section{KESIMPULAN}

Dari data di atas dapat disimpulan bahwa media pembelajaran berbasis virtual reality layak digunakan dalam pembelajaran.

\section{DAFTAR PUSTAKA}

Akbar, S. 2013. Instrumen Perangkat Pembelajaran. Bandung: Remaja Rosda Karya

Arikunto. 2010. Prosedur Penelitian: Suatu Pendekatan Praktek. Jakarta: PT. Rineka Cipta.

Arsyad, A. 2002. Media Pembelajaran. Jakarta: Raja Grafindo Persada.

Erwinsyah, Alfian. 2015. “Pemahaman Mengenai Teknologi Pendidikan dan Teknologi Pembelajaran." Jurnal Manajemen
Pendidikan Islam Vol. 3 No. 1, e-ISSN 2442-8280.

Firmansyah, et al. 2009. Mudah dan Aktif Belajar Biologi. Jakarta: Pusat Perbukuan Departemen Pendidikan Nasional.

Hasbiyati, H., \& Khusnah, L. (2016). Pengembangan E-Book Berekstensi Epub Pada Pembelajaran IPA SMP. Jurnal Bioshell, $5(1)$.

http://ejurnal.uij.ac.id/index.php/BIO/ar ticle/view/49

Musfiqon, H. M. 2012. Pengembangan Media $\mathcal{E}$ Sumber Pembelajaran. Jakarta: Prestasi Pustakarya.

Sadiman, Arief S., et al. 2014. Media Pendidikan. Pengertian, Pengembangan dan Pemanfaatannya. Jakarta: Rajawali Pers.

Setyosari, Punaji. 2012. Metode Penelitian Pendidikan dan Pengembangan. Jakarta: Kencana Prenadamedia Group.

Sugiyono. 2011. Metode Penelitian Kuantitatif, Kualitatif dan RED, Bandung :

Alfabeta.

2016. Metode Penelitian dan Pengembangan: Research and Development. Bandung: Alfabeta.

2017. Metode Penelitian dan Pengembangan: Research and Development. Bandung: Alfabeta.

Sukiman. 2012. Pengembangan Media Pembelajaran. Yogyakarta: Pedajogja. 